\title{
Litigating Agency Change: The Impact of the Courts and Administrative Appeals Process on the Forest Service
}

\section{Elise S. Jones and Cameron P. Taylor}

\begin{abstract}
A study of Forest Service-related litigation and administrative appeals was undertaken to examine their potential roles in effecting change within the Forest Service. The frequency of federal lawsuit decisions involving the Forest Service increased markedly between 1971 and 1993, indicating a dramatic increase in the use of litigation as a tool to force change within the agency, particularly in the Ninth Circuit. Administrative appeals followed a similar increasing trend. An examination of the instigators and purposes of lawsuits found that litigation is used most frequently by environmentalists and most often to block commodity production activities by the agency. Although the agency wins the majority of suits in which it is involved, litigants who initiated lawsuits to stop commodity production activities had higher success rates than litigants seeking to challenge additional environmental measures or to promote commodity production by the agency. A qualitative examination of five National Forest Management Act lawsuit case studies concluded that when litigants are successful in legal challenges against the agency, the court decision often results in substantive on-the-ground changes in management, thereby providing an incentive for additional use of litigation as a means to alter agency actions. These results indicate that the courts and administrative appeals process likely have been significant factors in catalyzing change within the Forest Service.
\end{abstract}

A major subject of recent debate is whether the United States Forest Service (USFS) has altered its management of the national forests to reflect the dramatic changes that have occurred in the political, social, economic, and ecological landscape since the agency was first created nearly a century ago. Specifically, scholars have been examining whether the Forest Service has moved away from its historic commodity focus on timber production, as described by Dana and Fairfax (1980) and Twight (1983), to embrace a more holistic management approach committed to the sustainable use and protection of an array of commodity and non-commodity forest uses. Several have concluded that the agency has progressed in this direction, particularly in recent years (although most also conclude that the agency still has much further to go). Evidence of this change has been documented in surveyed shifts in USFS employee attitudes and values (Mohai, Stillman, Jakes, \& Liggett, 1994; Brown \& Harris, 1992a, 1992b; McCarthy, Sabatier, \& Loomis, 1991), on-the-ground resource management activities (Farnham \& Mohai, 1995; Farnham, Taylor, \& Callaway, 1995), new trends in the agency's budget requests and congressional appropriations (Farnham, 1995), and surveyed perceptions of outside interest groups (Jones \& Mohai, 1995).

A related topic of analysis is the source of this perceived change. Several internal factors have been hypothesized as potential catalysts for change, including the recent influx of women, minorities, and non-foresters into the agency-employee groups that historically have been underrepresented within the Forest Service and that are thought to hold values and attitudes about resource management that differ from the agency's historical value orientation (Mohai \& Jakes, in press; Mohai, Stillman, Jakes, \& Liggett, 1994; Thomas \& Mohai, 1995; Brown \& Harris, 1993; Kennedy, 1991; 
McCarthy, Sabatier, \& Loomis, 1991). A number of external change agents also have been suggested and studied, including Congress and congressional legislation (Jones \& Callaway, 1995; Tipple \& Wellmann, 1991; Ackerman, 1990; Kennedy, 1988) and outside interest groups (Jones \& Mohai, 1995; Wenner, 1982; Culhane, 1981).

This paper examines the judicial system and administrative appeal process as potential catalysts of change within the Forest Service. In the early days of the Forest Service, the agency was relatively unencumbered by outside oversight from either the public or Congress, and its expertise and decisionmaking rarely were challenged in court (Kennedy, 1988). However, the multitude of environmental laws enacted in the 1960s and 1970s opened up agency decisionmaking processes to public scrutiny and input, and provided citizens with greater opportunities to challenge agency decisions both administratively and in court. A number of scholars argue that this increased public involvement via litigation and administrative appeals has forced federal agencies like the Forest Service to change the way they do business (Tipple \& Wellmann, 1991; Ackerman, 1990; Kennedy, 1988; Wenner, 1982). However, to date little to no data have been provided to link these legal challenges conclusively to perceived change within the Forest Service. This article attempts to fill that gap.

First, we will look at a brief history of the role of the courts and the administrative appeals process in national forest policy. Then we will conduct a quantitative analysis of Forest Service-related lawsuits and administrative appeals, examining the frequency, location, purpose, success rate, and instigators of these legal actions. Our hypothesis is that if litigation and appeals are important sources of agency change, then we should see a rise in the frequency of certain types of lawsuits and appeals as change within the Forest Service has increased. Although not conclusive proof alone, such a correlation would indicate these activities are likely factors in agency change. Finally, we will attempt to address the cause-and-effect question of whether lawsuits won against the agency result in on-the-ground changes in national forest management, by undertaking a qualitative examination of several important National Forest Management Act (NFMA) decisions and an assessment of participants' views of these cases' impacts.

\section{History of Judicial Review and Administrative Appeals}

\section{Judicial Review}

The use of the court system to challenge agency actions or inaction has evolved through the combination of laws enacted during the past few decades to facilitate citizen access to judicial review, and legal precedent set through case law.

The Administrative Procedure Act of 1946 (60 Stat. 237) dictates how agencies are supposed to promulgate rules and give notice to the public, and also addresses judicial review of agency actions (Plater, Abrams, \& Goldfarb, 1992). Most substantive challenges to agency decisions have focused on the subjective question of whether the agency's judgment was reasonable (Plater, Abrams, \& Goldfarb, 1992). Because the courts are hesitant to question an agency's discretion about a technical matter, public involvement under the Administrative Procedures Act has been limited to settling procedural issues (Parent, 1992). Therefore, private citizens traditionally sought resolutions to substantive environmental problems through the legislative and executive branches of the government (Cutler, 1972).

In addition to judicial deference to agency discretion, the issue of standing has been a major deterrent to citizen involvement in the judicial process. Historically, parties had no right to sue unless they could show individualized economic injury 
(Cutler, 1972). Then, in the mid-1960s, courts began to provide citizens with a much broader standing to sue (Plater, Abrams, \& Goldfarb, 1992). This trend toward more leniency resulted in an increase in court cases seeking to resolve environmental disputes in the 1960s and early 1970s (Cutler, 1972).

The 1970s marked a major change in citizen access to the courts via the passage of several landmark laws, which have contributed significantly to expanding public and judicial involvement in forest planning (Parent, 1992; Wenner, 1982). The National Environmental Policy Act (NEPA) of 1969 (83 Stat. 852, 42 U.S.C. 4321 et. seq.) was hailed as "perhaps the most significant federal environmental statute in the past two decades" (Plater, Abrams, \& Goldfarb, 1992, p. 656). NEPA requires agencies to write an environmental impact statement (EIS), including a detailed analysis of anticipated effects and alternative actions, before undertaking any "major Federal action significantly affecting the quality of the human environment" (42 U.S.C. 4332).

NEPA also requires that all Federal agencies "involve the affected and interested public in planning and analysis prior to making decisions" (57 Fed. Reg. 59: 10445). By mandating impact analyses and opportunities for citizen input according to a specified procedure, NEPA also broadened the role of the courts in undertaking procedural reviews of agency actions (Parent, 1992). Additionally, NEPA provided a broad base for standing to anyone who claims an environmental interest. This greatly improved citizen access to the courts, as evidenced by the fact that NEPA was the basis for more lawsuits than any other environmental law enacted in the 1970s (Wenner, 1982). For these reasons, many scholars credit NEPA with altering the agencies' relationship with the public; Kennedy $(1988$, p. 126) even goes so far as to describe NEPA as "the first major legislative assault" on the agency's traditional, utilitarian, and change-resistant values.

Another major statute, with perhaps the most wide-sweeping grant of citizen standing, is the Endangered Species Act (81 Stat. 884, 16 U.S.C. 1531-1544). This 1973 law absolutely prohibits federal actions harmful to a listed species, and thus permits "unexpected environmental lawsuits challenging a variety of federal agency actions" (Plater, Abrams, \& Goldfarb, 1992, p. 656).

In 1976, Congress passed the National Forest Management Act, further broadening the public's role by requiring that the Forest Service incorporate public input in the preparation of land and resource management plans for each administrative unit of the National Forest System (90 Stat. 2949, 16 U.S.C. 1600-1614). NFMA outlines in detail the process to be used in developing, adopting, and revising these plans and mandates multiple-use forest management.

The passage of these major statutes facilitated the use of the judicial system as a tool by citizen groups to force changes in agency behavior (Ackerman, 1990). However, subsequent court decisions have countered this tendency somewhat by requiring organizations to show that their individual members have suffered injury, based on impacts on their use of specific resources (Robichaud, 1991). Such rulings not only make it more difficult for environmental litigants to achieve standing without the aid of a specific citizen suit provision; it also will limit them to bringing lawsuits that challenge "a specific agency action rather than a broad agency program" (Robichaud, 1991, p. 471).

\section{Administrative Appeals Process}

The Forest Service's administrative appeals process is linked closely with the court system; before seeking judicial review of agency activities, groups, and individuals generally first must exhaust all available administrative remedies (Parent, 
1992). The purpose of the appeals process has been "to give the public an informal avenue for review and resolution of disputed agency decisions without the necessity of litigation" (57 Fed. Reg. 59: 10445). Although not dictated historically by statute, the Forest Service voluntarily provided a forum for citizen review of agency decisions beginning as far back as 1906 (54 Fed. Reg. 13). According to agency staff, heavy use of the appeals process has been a relatively recent phenomenon beginning in the last 5 years (Coulombe, 1993).

Increasingly, external interest groups have come to view access to administrative review of agency decisions as a very powerful tool for affecting management of the country's national forests (Bolduan, 1990). Reports one environmental group: "Given the Forest Service's history of non-compliance with federal regulations, citizen enforcement is crucial to the effectiveness of any legislation regarding our federal lands" (Save America's Forests, 1992a, p. 1).

The Forest Service has reported some positive effects from administrative appeals. A 1990 agency study claimed: "It would be safe to say that the appeals process has made us better implementers of NEPA, which results in better decisionmaking. This, in turn, results in better land management" (United States Department of Agriculture, Forest Service, 1990b, p. 15).

More often, however, the Forest Service takes a negative view of administrative appeals, maintaining that they have become a "significant generator of paperwork and a time-consuming, procedurally onerous, confrontational, and costly effort, diverting resources that otherwise might be directed to substantive on-the-ground resource management needs and accomplishments" (57 Fed. Reg. 59: 10445). Coulombe (1993), claims: "Now they [administrative appeals] are being used as an overt, all-out effort to challenge the Forest Service's management." She adds, "People are using [them] as a vehicle to address much bigger social and economic objectives." Exact costs are difficult to determine, but, according to the Forest Service, a "rough estimate" of the administrative costs of appeals in 1991 was about $\$ 11$ million (Coulombe, 1993), and in fiscal year 1992, roughly 131 full-time equivalents in personnel were required to process appeals (United States Department of Agriculture, Office of the General Counsel, 1993).

The impact and costs of appeals have caused both the Forest Service and Congress to spearhead efforts to restrict their use. At least six times in the last decade, Congress has attached a "rider" to the annual appropriation bill for the Forest Service that either prohibited or severely constrained legal challenges of agency actions, usually timber sales (Jones \& Callaway, 1995). In 1989, and again in 1992, the Forest Service attempted to streamline its appeals process to help, among other things, "remove impediments to economic growth arising from the current appeals process" (57 Fed. Reg. 59: 10444). Congress then took matters into its own hands, by revamping the Forest Service appeals process in the Fiscal Year 1993 Interior Appropriations bill.

These initiatives to reduce access to judicial review and the administrative appeals process have been opposed adamantly by forces interested in maintaining citizen involvement in and review of agency decisionmaking. Claims the Association of Forest Service Employees for Environmental Ethics (AFSEEE), "the current appeals process has been positive because it has given citizens an additional oversight role in national forest management.... The agency should be trying to figure out why so many community and environmental groups are appealing ... rather than trying to stop the appeals process altogether" (Inner Voice, 1992, p. 3). In summarizing comments on the agency's 1989 draft proposal, the agency itself recognized this public relations danger: 
The proposed rule provoked considerable general comment, largely critical, on the relationship between the Forest Service and the public.... There were a substantial number of people who feel that by tightening the appeals rules, the Forest Service is trying to close a legitimate avenue of involvement... The "trust" and "bad faith" comments are legitimate, if troubling, expressions of public concern (54 Fed.Reg. 13: 3343-3344).

These comments indicate that reducing the opportunity costs of appeals also may carry large public image costs for the agency.

\section{Methods}

A quantitative assessment of judicial decisions and administrative appeals involving the Forest Service was undertaken to analyze trends in the use of the court system and the appeals process to force agency change. This analysis was done in two stages.

First, data on lawsuits involving the Forest Service were gathered from the WestLaw computerized database, which compiles all cases published in the West Reporter System and Environmental Law Reporter. A general list of Forest Service lawsuits was obtained via a March 1993 WestLaw computer search for all federal court cases decided after 1976 that mentioned "Forest Service" in the text and included the agency's name in the descriptive paragraph at the beginning of the case. This search procedure was used because not all suits to which the Forest Service is a party actually name the agency in the case title (often, individual Forest Service personnel are sued). Conversely, a computer search of all lawsuits mentioning the Forest Service in their text would have yielded many cases that did not pertain to the agency. The method chosen generated a list of 271 cases, which then were used to illustrate trends in the overall frequency of use of the judicial system to influence Forest Service actions.

Next, for a more in-depth analysis, a list of NFMA-cited cases was obtained from the USDA's Office of General Counsel, which undertook a WestLaw computer search in December 1992 for all federal court cases including the key terms "N.F.M.A." and "National Forest" or "Forest Service" (Mulach, 1993). This list then was edited to remove any cases that were not concerned primarily with the National Forest System or the Forest Service, to yield a total of 67 cases: 1 Supreme Court case, 20 suits from the appellate level, 42 district court cases and 4 suits brought in Federal Claims court. In addition, a list of all cases published by the WestLaw Publishing Company that involved Forest Service NEPA documents (environmental impact statements or environmental assessments) also was obtained from the USDA Office of General Counsel. Consisting of all cases from 1971 through 1992, this NEPA list included 58 district court cases and 41 appellate-level lawsuits, for a total of 99 cases. These NFMA and NEPA lawsuits then were analyzed according to five different variables: date of decision, court in which the suit was brought, identity of the plaintiff or appellant initiating the suit, purpose of the suit, and whether the plaintiffs or appellants successfully achieved their NFMA or NEPA objective.

Several shortcomings of this methodology should be noted. First, it examines only suits that have been decided, thereby overlooking pending cases and suits settled out of court, neither of which are on a database nor have an easily accessed paper trail. For example, in January 1993, there were more than 34 pending NFMA cases (United States Department of Agriculture, Office of the General Counsel, 1993). Although the WestLaw Publishing series is "the official and most comprehensive reporter of legal 
published cases (Vail, 1993, p. 1). Similarly, this analysis includes only published cases; courts occasionally rule on lawsuits without publishing their decisions (which makes it very difficult to obtain information on the cases). Generally, unpublished cases do not set legal precedent. The Forest Service did not keep record of unpublished decisions prior to 1989, but reports that at least 23 unpublished NEPA cases have been decided since 1989. Similarly, the NEPA and NFMA cases analyzed represent less than $50 \%$ of all cases that have been brought against the Forest Service in the past two decades.

Lawsuits involving the agency can be based on a whole range of other environmental laws, such as the Endangered Species Act, the Wilderness Act, and the Clean Water Act, to name just a few, and most suits base their arguments on a number of statutes and regulations. For example, the Office of General Counsel reports that roughly $47 \%$ of the cases on our NEPA list also are crosslisted on the NFMA list (Vail, 1993). Additionally, although NFMA was cited in all of the cases analyzed on the NFMA list, it was not always the pivotal statute affecting the outcome of the case; nonetheless, "success" was based on the results of the NFMA argument, rather than the overall case, to assess the impact of the statute. This same approach was followed with the NEPA analysis. This distinction, however, affected only a small number of cases. Also, in a handful of cases, determining "success" was a slightly subjective undertaking. In two NFMA and two NEPA cases a "remand" was reported, and one NFMA case was categorized as "mixed." Lastly, while the more meaningful timing measurement would have been the date when each suit was brought, these data largely are unavailable; therefore, the date of the court ruling was used instead.

Despite these limitations, this analysis provides a good picture of how the court system is accessed to attempt changes in Forest Service management behavior. If anything, it provides a conservative estimate of the potential impact of court cases as a tool to achieve agency changes, because we do not report undecided or unpublished decisions, and because the mere threat of lawsuits may impact decisionmaking. Moreover, it is agreed widely in the environmental legal community that NFMA is not the most effective litigation tool among the environmental statutes, due to the fact that much of the law is broad and process-oriented in nature (Honnold, 1993).

Quantitative data on administrative appeals of Forest Service decisions was obtained from the Forest Service's Washington Office. Data were collected on the total number of appeals brought against the agency, the number brought in each Forest Service region, and the frequency and nature of the appeal decisions rendered by the agency. Unfortunately, the agency only recently has begun collecting detailed data on appeals, so no information is available for years prior to 1986 , and relatively little is known regarding the type of litigants who have initiated appeals.

In addition to this quantitative analysis, a more in-depth qualitative analysis was undertaken to assess the on-the-ground impact of successful lawsuits against the Forest Service and to attempt to establish a cause-and-effect link between legal challenges and agency change. Specifically, court decisions were analyzed involving the legal adequacy or development of the land resource management plans or forest planning mandated by NFMA. Such decisions are particularly important given the precedent they will set for future forest planning and the overall potential impact of the NFMA forest planning process upon National Forest management.

The Office of the General Counsel reports that 20 federal court cases had been decided as of January 1993 specifically regarding NFMA forest planning or land resource management plans (United States Department of Agriculture, Office of the General Counsel, 1993). This relatively small number of decisions occurs because plans for many forests have been completed only recently and appeals of them that 
have had to work their way up through the administrative appeals process are just now reaching the courts (United States Department of Agriculture, Forest Service, 1990a). Of these 20 decisions, according to the Office of the General Counsel's January 1993 LMRP/NFMA Forest Planning Litigation Scorecard, the Forest Service has won 16 of the cases and lost 5 (one case had mixed results and hence was counted in both categories). All five cases were brought by environmental organizations seeking to force the Forest Service to amend forest plans either to lower timber cut levels or to increase protection for the northern spotted owl. These five agency "defeats" were chosen for analysis under the assumption that only lawsuits that the Forest Service loses are likely to result in substantive changes in forest management. It should be recognized, however, that this assumption might result in an understatement of judicial impact, because the mere threat of bringing a lawsuit may impact agency behavior (Culhane, 1981). Additionally, the costs and delays associated with litigation may effect change regardless of the court's final decision.

Phone interviews were conducted with eight representatives of the Forest Service and of the environmental community who were either involved directly with one of the court cases and/or particularly knowledgeable about subsequent on-theground management activities in the affected forest. Interview questions focused on whether or not the court decision against the agency had resulted in any actual change in the agency's management activities.

\section{Quantitative Analysis of Judicial Review and Administrative Appeals}

\section{Judicial Review}

To assess the potential impact the judicial system has had and potentially will have on the Forest Service, it is necessary to examine the courts as a vehicle for influencing agency behavior: (a) Have there been many judicial rulings directly affecting the Forest Service? (b) Have these decisions impeded, or facilitated, change within the agency? (c) Does the mere threat of litigation instigate change? Courts do not initiate judicial action themselves; their review of agency actions is limited to the cases brought to their attention by individuals or organizations dissatisfied with an agency's decisions and activities. As a result, the potential for the judicial system to facilitate or impede agency change is linked directly to actors who have the qualifications, resources, expertise, and desire to access the courts successfully. Therefore, it is necessary also to answer such questions as: (a) Who are the primary initiators of judicial actions against the Forest Service? (b) What goals are they trying to achieve? (c) Are these policy actors successful in attaining these objectives?

\section{Use of the Courts}

Figure 1 illustrates the frequency of federal court decisions for all lawsuits involving the Forest Service brought in the Supreme Court, and in Claims, Tax, appellate, and district courts from 1977 to 1992 (including both original decisions and appealed decisions for the same case). There is a steadily increasing trend of court decisions throughout the period, indicating a growing use of the judicial system by interest groups, commodity interests, and citizens dissatisfied with the agency's decisions. As mentioned earlier, this represents an understatement of the use of the judicial system because neither pending nor unpublished cases have been reported. It is also important to remember that there is a lag between when the cases were initiated and when they were decided. 


\section{Figure 1}

\section{Frequency of All Lawsuits Involving the Forest Service}

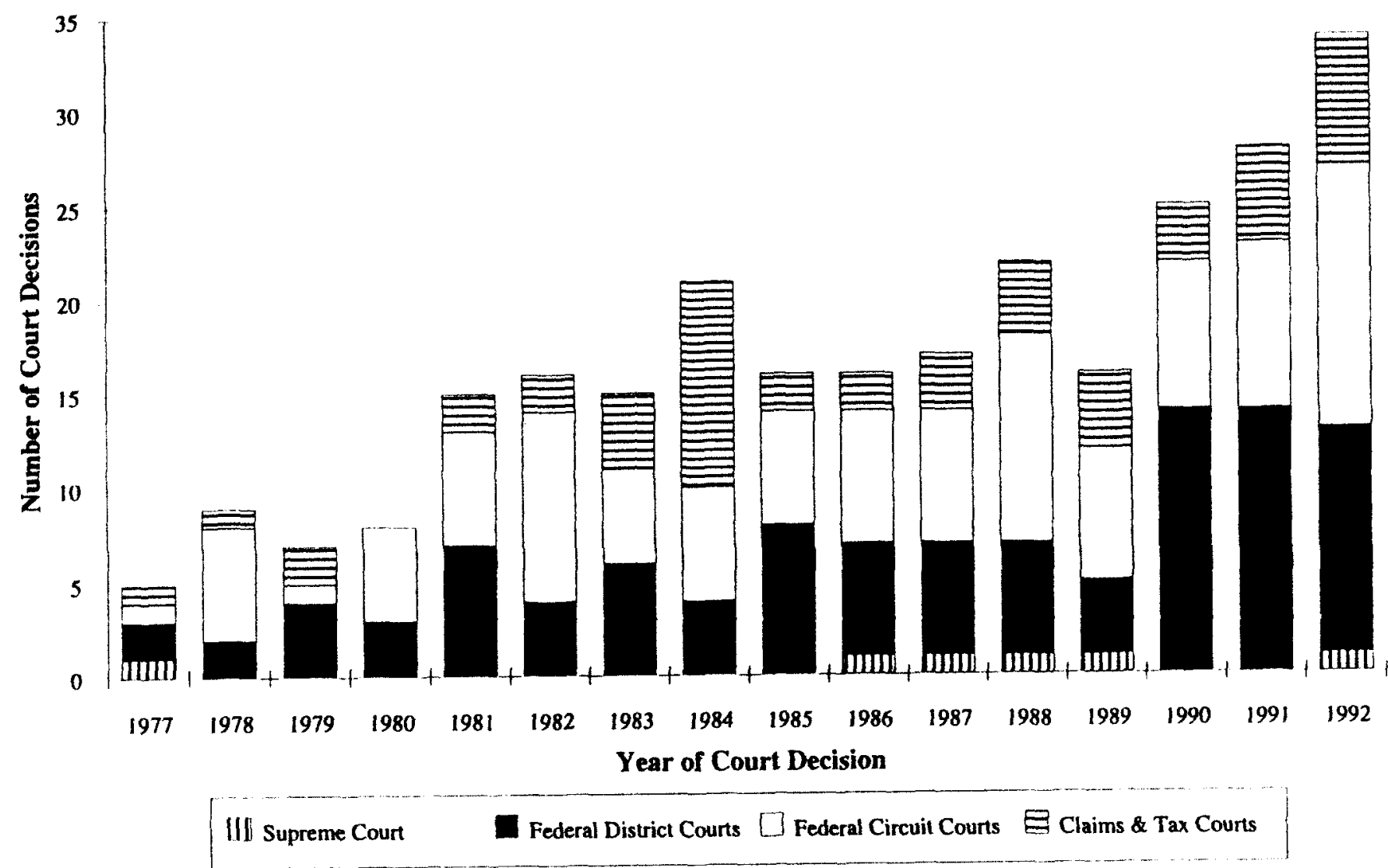

Looking at NFMA cases specifically, the same upward trend can be seen in Figure 2, with the increase beginning in the mid-1980s. Roughly two NFMA decisions were published annually between 1977 and 1984, after which decisions increased dramatically, with dips in 1987 and 1989, to a high of 12 in 1991. A similar, but more subtle, trend was found for NEPA cases, as seen in Figure 3, with decisions vacillating between 1 and 4 through the 1970s, and increasing through the 1980s to highs of ten or above in 1985 and 1992.

Such increases are to be expected with growing use of the administrative appeals process, the recent advent of completed forest plans that are starting to be challenged, and the arrival of other appealed cases making their way slowly through the judicial system hierarchy. This trend also coincides with the growing availability of legal expertise and resources among interest groups, particularly environmental organizations, and is indicative of the growing demand for public involvement in Forest Service decisionmaking (Tipple \& Wellmann, 1991). The recent Supreme Court decisions on standing, however, may inhibit the trend of using courts as a forum for airing grievances about management of the National Forests.

Figure 2 also illustrates the increased number of NFMA decisions regarding the northern spotted owl, climbing from zero in 1988 to five in 1992. Although these 
cases parallel the general increase in NFMA cases, they are not responsible solely for it, nor is the spotted owl the only endangered species controversy being litigated with the Forest Service.

\section{Location of Lawsuits}

Lawsuits involving the Forest Service are not distributed evenly throughout the country or its judicial system. As depicted in Table 1, the bulk of district-level NFMA suits are brought in the western portion of the country, with California, Washington, and Montana taking the lead. The trend is even more striking on the appellate court level, as seen in Table 2, where $64 \%$ of the cases are brought in the Ninth Circuit, which encompasses the states of Oregon, Washington, California, Nevada, Idaho, Montana, and Alaska. NEPA litigation exhibits a similar pattern: Oregon, Montana, and California are the three most litigious states on the district court level, and the Ninth Circuit is the site of roughly $64 \%$ of all appellate-level cases.

There are several reasons for this significant skew. This region of the country is the site of significant timber harvesting activity and is home to the northern spotted owl, factors which combine to create volatile conflict between the goals of timber production and environmental protection. According to many attorneys interviewed,

\section{Figure 2}

Frequency of NFMA Lawsuits Involving the Forest Service
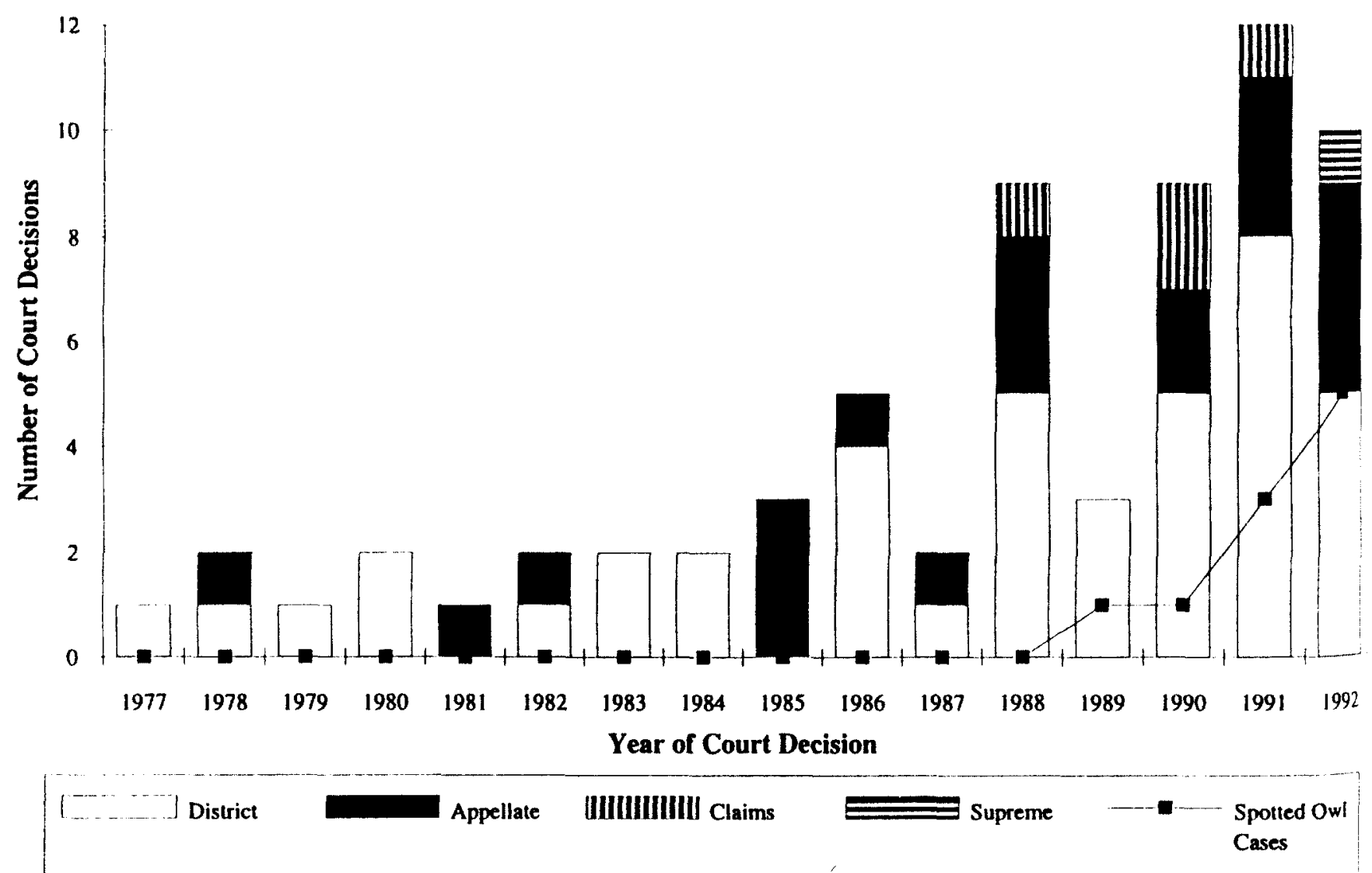


\section{Figure 3}

\section{Frequency of NEPA Lawsuits Involving the Forest Service}

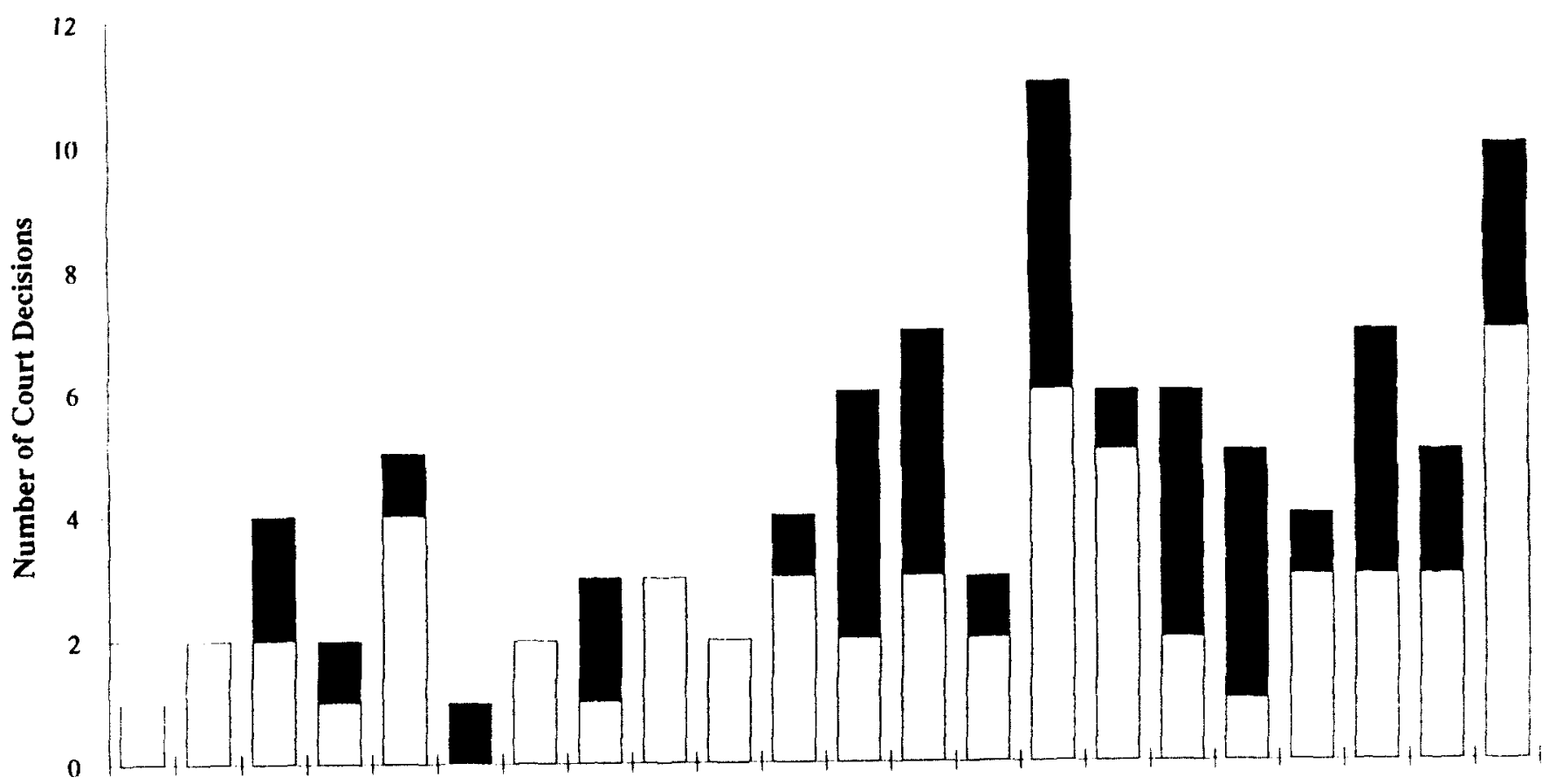

$197119721973 \quad 1974 \quad 197519761977197819791980198119821983198419851986198719881989199019911992$ Year of Court Decision

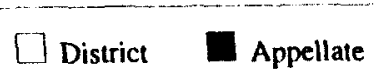

the Ninth Circuit Court is also considered the most favorable circuit to environmental concerns, in part because it has more experience with the subject matter due to the high frequency of environmental cases it sees, and hence is a preferred locale for bringing such suits. This view is bolstered by the fact that litigants, the bulk of whom are environmentalists, were successful in about $45 \%$ and $68 \%$ of their NFMA and NEPA suits in the Ninth Circuit, respectively, compared to much lower overall success rates at the appellate level or in the judicial system as a whole. As a result, litigation appears more likely to be a vehicle for change within the Forest Service in this region of the country.

\section{Litigant Type and Purpose of NFMA Suits}

The plaintiffs and appellants who initiated NFMA lawsuits were divided into four general categories: (a) environmentalists (including individuals; citizen councils; and state, local, and national environmental organizations); (b) commodity interests (timber and mining companies, ranching associations, commercial fishing interests, and law firms that litigate for commodity interests); (c) Native Americans; and (d) governments (including states, cities, and counties). In the 5 NFMA and 10 NEPA cases that multiple litigant types initiated the suits, each litigant type received credit.

Figure 4 depicts the relative frequency of NFMA cases brought by each litigant category. Environmentalists were by far the most common litigants, in about $60 \%$ of all NFMA suits against the Forest Service. Commodity interests also litigated a substantial amount, having participated in 17 NFMA actions against the agency, 


\section{Table 1}

Location and Outcome of Federal District Court Decisions on NFMA and NEPA Lawsuits Involving the Forest Service

\begin{tabular}{|c|c|c|c|c|c|c|}
\hline \multirow[b]{3}{*}{ State } & \multicolumn{3}{|c|}{ NFMA Lawsuits } & \multicolumn{3}{|c|}{ NEPA Lawsuits } \\
\hline & USFS & USFS & Mixed & USFS & USFS & Mixed \\
\hline & Won & Lost & Result & Won & Lost & Result \\
\hline AK & 2 & 0 & 0 & 1 & 2 & 1 \\
\hline $\mathrm{AL}$ & 0 & 0 & 0 & 1 & 0 & 0 \\
\hline AR & 1 & 1 & 0 & 2 & 0 & 0 \\
\hline $\mathrm{CA}$ & 4 & 4 & 0 & 2 & 3 & 0 \\
\hline $\mathrm{CO}$ & 0 & 1 & 1 & 2 & 0 & 0 \\
\hline $\mathrm{DC}$ & 0 & 0 & 0 & 2 & 1 & 0 \\
\hline GA & 2 & 0 & 0 & 0 & 0 & 0 \\
\hline ID & 2 & 0 & 0 & 1 & 0 & 1 \\
\hline IL & 1 & 0 & 0 & 3 & 0 & 0 \\
\hline MI & 0 & 0 & 0 & 0 & 1 & 0 \\
\hline $\mathrm{MN}$ & 1 & 0 & 0 & 2 & 1 & 0 \\
\hline MT & 5 & 0 & 0 & 3 & 5 & 0 \\
\hline OR & 3 & 1 & 0 & 5 & 4 & 0 \\
\hline PR & 0 & 0 & 0 & 0 & 1 & 0 \\
\hline SD & 0 & 0 & 0 & 1 & 0 & 0 \\
\hline $\mathrm{TX}$ & 2 & 2 & 0 & 3 & 1 & 0 \\
\hline WA & 2 & 4 & 0 & 2 & 1 & 0 \\
\hline WV & 0 & 0 & 0 & 1 & 0 & 0 \\
\hline WI & 1 & 0 & 0 & 0 & 1 & 0 \\
\hline WY & 1 & 2 & 0 & 3 & 1 & 0 \\
\hline
\end{tabular}

\section{Table 2}

Location and Outcome of Federal Appellate Court Decisions on NFMA and NEPA Lawsuits Involving the Forest Service

\begin{tabular}{lcccccc}
\hline & \multicolumn{3}{c}{ NFMA Lawsuits } & \multicolumn{3}{c}{ NEPA Lawsuits } \\
Court & USFS & USFS & Mixed & USFS & USFS & Mixed \\
Location & Won & Lost & Result & Won & Lost & Result \\
5th Cir. & 1 & 0 & 0 & 1 & 0 & 0 \\
7th Cir. & 1 & 0 & 0 & 1 & 0 & 0 \\
8th Cir. & 0 & 0 & 0 & 3 & 1 & 0 \\
9th Cir. & 4 & 9 & 1 & 8 & 17 & 1 \\
10th Cir. & 0 & 0 & 0 & 3 & 2 & 1 \\
D.C. & 0 & 1 & 0 & 2 & 1 & 0 \\
Ct. Cl. & 0 & 1 & 0 & 0 & 0 & 0 \\
Claims Court & 0 & 1 & 0 & 0 & 0 & 0 \\
Federal Circuit & 1 & 1 & 0 & 0 & 0 & 0 \\
Supreme Court & 1 & 0 & 0 & 0 & 0 & 0 \\
& & & & & & \\
\hline
\end{tabular}




\section{Figure 4}

\section{Purposes and Litigants of NFMA Lawsuits Against the Forest Service}

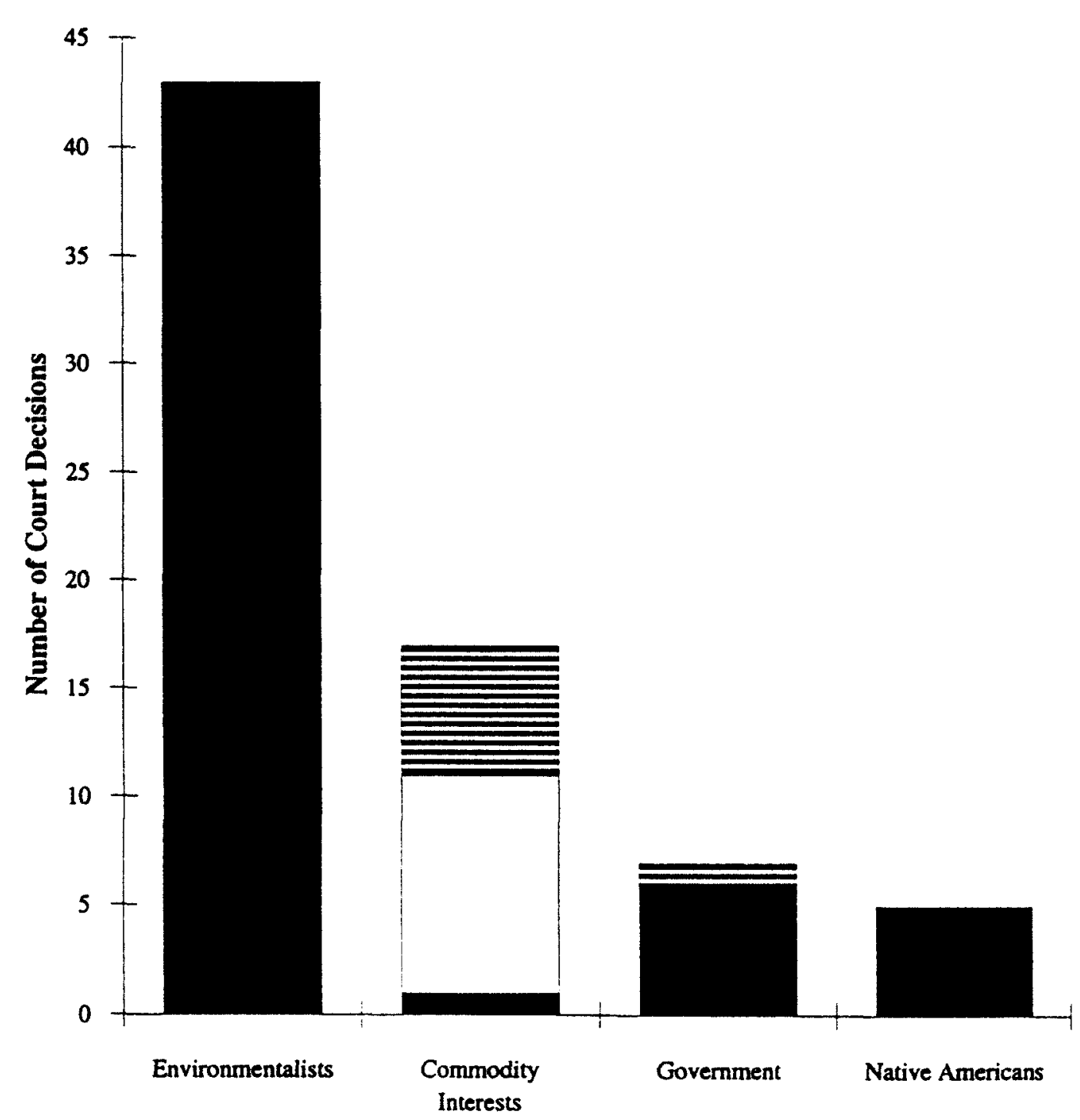

Type of Litigant

\begin{tabular}{|ll|}
$\begin{array}{l}\text { To Block Commodity } \\
\text { Production }\end{array}$ & - To Settle Timber Sale \\
Contract Disputes & $\begin{array}{l}\text { To Block Environmental } \\
\text { Measures }\end{array}$ \\
\hline
\end{tabular}

followed by the government and Native American litigants, who were involved in 7 and 5 cases, respectively. It should be noted, however, that the 5 Native American suits all involved the same group, the Northwest Indian Cemetery Protective Association, in different decisions regarding the same initial suit. NEPA lawsuits exhibited an even greater spread between litigant types (Figure 5). Environmentalists initiated nearly $70 \%$ of all cases, followed by government entities, which were involved in 15 cases. Commodity interests and Native Americans participated in 10 and 11 NEPA lawsuits, respectively.

Next, the purposes of the lawsuits were categorized according to the goal being sought by the litigants. Lawsuit purposes were lumped together into four broad 
Policy Studies Journal, 23: 2

categories for the purposes of analysis: to block commodity production activities by the Forest Service, to promote greater commodity production of national forest resources (NEPA only), to challenge additional environmental protection measures being proposed or implemented by the agency, and to settle timber sale contract disputes (NFMA only). Of the 67 NFMA-cited suits, the vast majority-about 75\%were brought to block the agency from approving, planning for, or engaging in a commodity production activity, typically involving timber harvests, or to force the agency to meet its NFMA obligation to ensure the viability of species within the National Forests. This was the purpose of all the suits involving environmentalists and Native Americans, and six out of seven of government NFMA suits. Commodity interests were slightly more varied in their purpose for initiating NFMA cases. Ten

\section{Figure 5}

Purposes and Litigants of NEPA Lawsuits Against the Forest Service

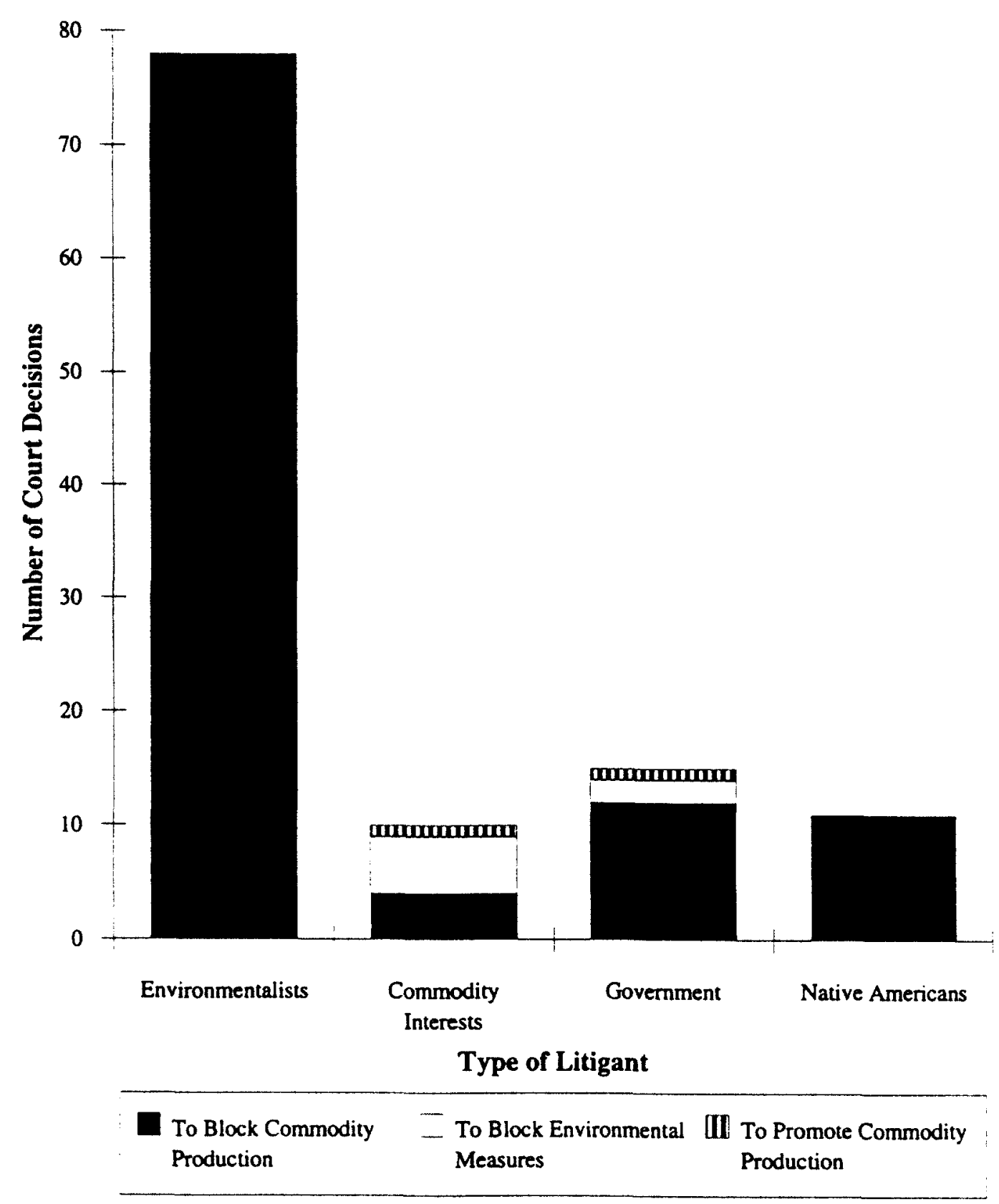


actions involved disputes with the Forest Service over timber sale contracts. Six sought to challenge the agency's attempts to provide for greater natural resource protection via the lowering of timber cut levels, the withdrawal of lands from mineral development, the development and implementation of use designations, or guidelines for management of an endangered species. In addition, one commodity interest suit brought by a ranching association attempted to enjoin timber harvest and road construction activities.

Ninety-two percent of NEPA lawsuits were brought to block commodity production activities by the Forest Service, most frequently timber harvest and roadbuilding activities, mineral or oil and gas extraction activities, or the spraying of pesticides. This was the purpose of all the suits initiated by environmentalists and Native Americans, and $80 \%$ of the cases in which governmental entities participated. Additionally, in four suits, commodity interests-ranchers, adjacent landowners, and commercial fishermen-participated with other litigant types in trying to stop Forest Service roadbuilding and timber harvest activities. Seven other cases initiated by government or commodity interests were brought either to promote commodity activities such as timber harvesting or water diversions, or to challenge non-commodity activities by the agency, such as the implementation of a land resource management plan or restriction of mining activities.

These results indicate that the judicial system is being used by a variety of interests to seek change within the Forest Service, including both those seeking greater resource protection in National Forests and those seeking consumptive resource use or development in these same areas. However, it reveals also that environmentalists were much more likely to use litigation as a tool to seek the changes they desire in National Forest management. This may be due at least partially to the agency's historic emphasis on timber production (Twight, 1983; Dana \& Fairfax, 1980), which leaves commodity interests with less need to litigate to achieve their interests. Moreover, most environmental statutes used in litigation against the agency, such as NFMA, were enacted to shift the emphasis of National Forest management away from commodity production, in favor of resource protection (Wenner, 1982), and hence are likely to be less useful in achieving increases in consumptive uses.

\section{Success in Achieving Lawsuit Objectives}

Finally, the likelihood that initiators of lawsuits would obtain their respective goals via the judicial system was examined. With lawsuits brought by multiple litigant types, each litigant received credit for the outcome of the case. The five "mixed result" and "remand" cases were credited as Forest Service losses for the purposes of calculating litigant success rates, because the litigants in these cases were at least partially successful in delaying or altering a Forest Service action, thereby providing an incentive for additional use of the courts as a means to leverage agency change. Success was calculated separately for district-level and appellate level cases, to illustrate differences in success between the two court levels. Then, these were combined in a "final outcome total" by deleting all district decisions that were appealed (to prevent double-counting of the decision), to illustrate the final outcome of the NFMA or NEPA claim. The results, along with success rates for the Forest Service, are shown in Tables 3 and 4.

The results indicate that the overall odds of plaintiffs and appellants "winning" lawsuits against the Forest Service are about $37 \%$ for NFMA cases and $45 \%$ for NEPA cases. In only 21 of the 57 NFMA decisions (the number of decisions after appealed lower-court decisions are eliminated) were plaintiffs and appellants successful at least temporarily in obtaining the objective of their lawsuits (only partially so in 2 cases) such as an injunction on timber sale activities or a favorable resolution to a contract 
Table 3

Success of Different Litigants in NFMA Lawsuits Against the Forest Service

\begin{tabular}{lrcr}
\hline Environmentalists & $\begin{array}{c}\text { District/Claims } \\
\text { Court }\end{array}$ & $\begin{array}{c}\text { Appellate/Supreme } \\
\text { Court }\end{array}$ & $\begin{array}{c}\text { Final Outcome } \\
\text { Total }\end{array}$ \\
Won & 11 & 3 & 10 \\
Lost & 17 & 9 & 23 \\
Mixed/Remanded & 1 & 1 & 2 \\
Percent Success & 41 & 31 & 34 \\
Commodity Interests & & 3 & 6 \\
Won & 3 & 1 & 10 \\
Lost & 10 & 0 & 0 \\
Mixed/Remanded & 0 & 75 & 38 \\
Percent Success & 23 & & \\
Government & & 3 & 3 \\
Won & 1 & 0 & 0 \\
Lost & 3 & 0 & 50 \\
Mixed/Remanded & 0 & 100 & 2 \\
Percent Success & 25 & & 2 \\
Native Americans & & 2 & 0 \\
Won & 1 & 0 & 50 \\
Lost & 2 & 0 & 36 \\
Mixed/Remanded & 0 & 100 & 19 \\
Percent Success & 33 & & 2 \\
Forest Service & & 10 & 63 \\
Won & 30 & 9 & \\
Lost & 16 & 1 & \\
Mixed/Remanded & 1 & 50 & \\
Percent Success & 64 & & \\
\hline
\end{tabular}

dispute-while the agency was victorious in the other 36 court decisions. Of the 77 NEPA cases (the total after excluding appealed lower-court decisions), litigants won 35 against the Forest Service (including 3 remanded cases), compared to the agency's 42 wins.

As shown in Table 3, environmentalists were successful in NFMA litigation efforts only $34 \%$ of the time; their commodity interest counterparts had somewhat higher success rate of $38 \%$. While the sample size for the government and Native American litigants was too small to be indicative of a trend, each had success rates of $50 \%$. With NEPA cases, environmentalists had a higher success rate, of $45 \%$. Commodity interests and the government exhibited higher success rates of $50 \%$ and $62 \%$, respectively, while Native Americans had a lower rate of $38 \%$ (see Table 4). However, the results for these three litigant types are likely to be skewed by the relatively small sizes of these categories.

It is perhaps more telling, if examined by purpose category rather than litigant type, that those involved in NFMA suits to impede commodity production activities or to promote environmental protection measures and non-commodity uses within the National Forest system had a $37 \%$ chance of obtaining a favorable court decision, while litigants challenging additional resource protection efforts or non-commodity forest 
Table 4

Success of Different Litigants in NEPA Lawsuits Against the Forest Service

\begin{tabular}{lccc}
\hline Environmentalists & $\begin{array}{c}\text { District/Claims } \\
\text { Court }\end{array}$ & $\begin{array}{c}\text { Appellate/Supreme } \\
\text { Court }\end{array}$ & $\begin{array}{c}\text { Final Outcome } \\
\text { Total }\end{array}$ \\
Won & 16 & 18 & 24 \\
Lost & 28 & 13 & 32 \\
Mixed/Remanded & 1 & 1 & 2 \\
Percent Success & 38 & 59 & 45 \\
Commodity Interests & & & \\
Won & 3 & 1 & 4 \\
Lost & 4 & 2 & 4 \\
Mixed/Remanded & 0 & 0 & 0 \\
Percent Success & 43 & 33 & 50 \\
Government & & & \\
Won & 3 & 5 & 7 \\
Lost & 4 & 1 & 5 \\
Mixed/Remanded & 0 & 75 & 62 \\
Percent Success & 43 & & \\
Native Americans & & 3 & 3 \\
Won & 1 & 4 & 5 \\
Lost & 1 & 0 & 0 \\
Mixed/Remanded & 0 & 43 & 38 \\
Percent Success & 50 & & \\
Forest Service & & 18 & 42 \\
Won & 35 & 21 & 32 \\
Lost & 22 & 2 & 3 \\
Mixed/Remanded & 1 & 44 & 55 \\
Percent Success & 60 & & \\
& & & \\
\hline
\end{tabular}

uses by the agency were successful only $29 \%$ of the time (Figure 6). Forty-four percent of the contract dispute decisions favored the litigants. This contrast is even greater with NEPA suits, as seen in Figure 7, where litigants attempting to stop the Forest Service from engaging in commodity production activities had a success rate of $46 \%$, while those using NEPA to challenge additional environmental measures or promote commodity activities by the agency had only a $20 \%$ success rate. These results indicate that judicial interpretations of NFMA and NEPA decisions have favored those seeking non-consumptive uses of the National Forests more than those seeking consumptive uses. The fact that NFMA has not been used as successfully as NEPA as a tool to force the agency to shift its emphasis to non-commodity forest uses is consistent with the views of legal scholars that, due in part to NFMA's discretionary language, the courts have "failed to take full advantage of NFMA" as "a vehicle in which to abandon their extreme deference and block agency decisions that do not meet legislative mandates" (Parent, 1992, p. 699).

\section{Administrative Appeals}

A quantitative analysis of administrative appeals also was undertaken, to test our hypothesis that if legal challenges to agency decisions are playing a role in 
influencing recent agency change, we will find an increase in the use of the administrative appeals process.

\section{Frequency of Appeals and Decisions}

Table 5 illustrates the steep increase in appeals initiated between 1986 and 1992, rising from 1,081 in 1986 to a record high of 1,991 in 1990. The majority of appeals relate to timber sales, ranging from 44\% of all appeals in 1989 to $57 \%$ in 1990, but other high categories include land management planning and recreation (Coulombe, 1993). This indicates that timber management is the most controversial activity in which the agency engages, and it illustrates a high level of frustration with the agency's timber policies among at least a segment of the American public Not surprisingly, appeals of Forest Service decisions are not uniform throughout the National Forest System. As seen in Table 6, Regions 6 (Pacific Northwest) and 8 (Southern Region)regions with particularly high timber activity-have been the sites of the most appeals (Hill, 1988; Hauser, 1990; United States Department of Agriculture, Forest Service, 1991).

Table 5 shows that for the most recent seven years, the Forest Service has received more appeals than it has decided (United States Department of Agriculture, Office of the General Counsel, 1993). The result has been a reported doubling of the workload and a continuous backlog of appeals (United States Department of Agriculture, Office of the General Counsel, 1993). In 1991, the agency reported that it took an average of 91 days to render an average project appeal decision and 102 days

\section{Figure 6}

Success of Litigants Pursuing Different Goals in NFMA Lawsuits Against the Forest Service

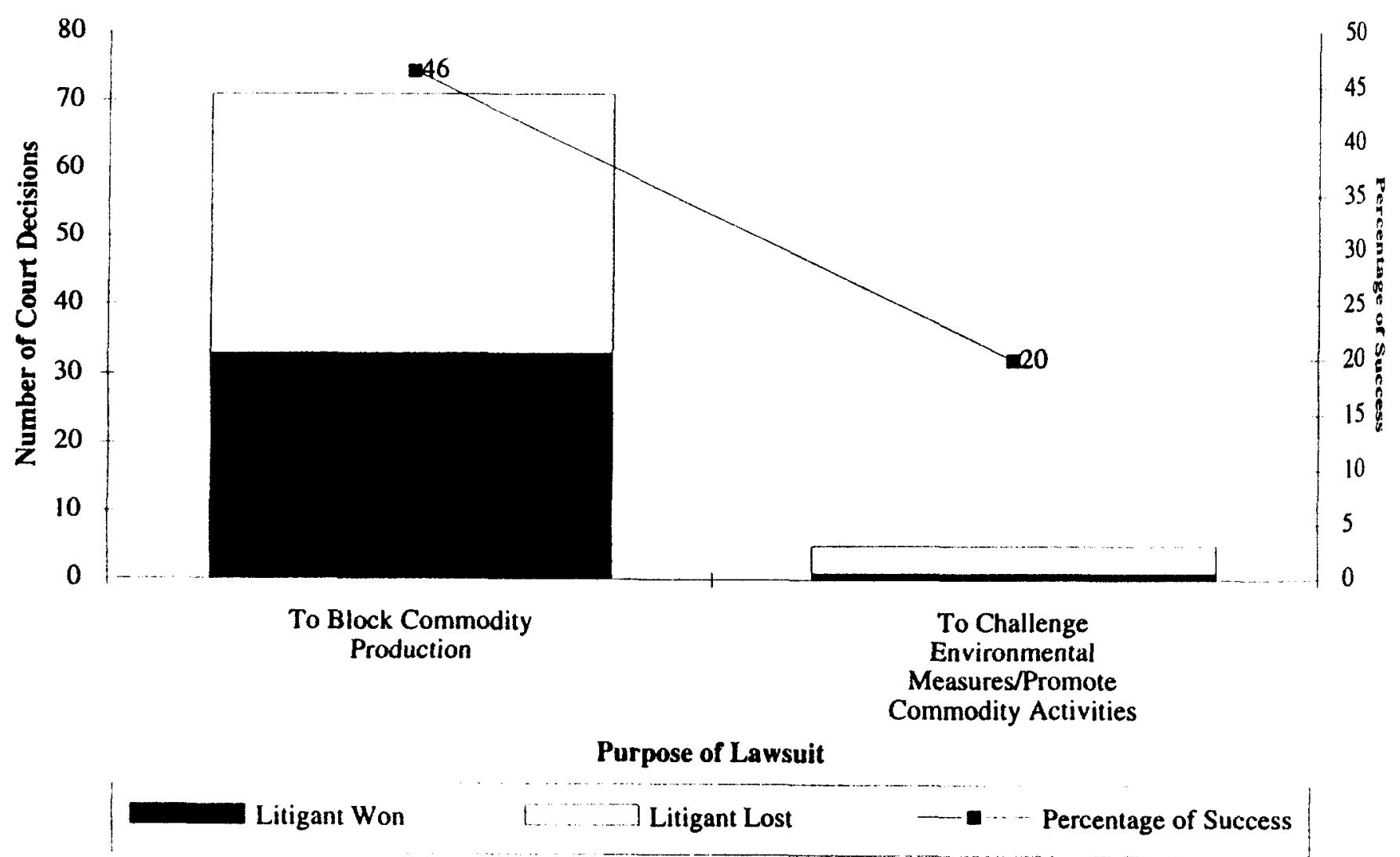


Symposium on Forest Service: Jones/Taylor to decide a timber sale appeal (United States Department of Agriculture, Forest Service, 1991).

\section{Figure 7}

Success of Litigants Pursuing Different Goals in NEPA Lawsuits Against the Forest Service

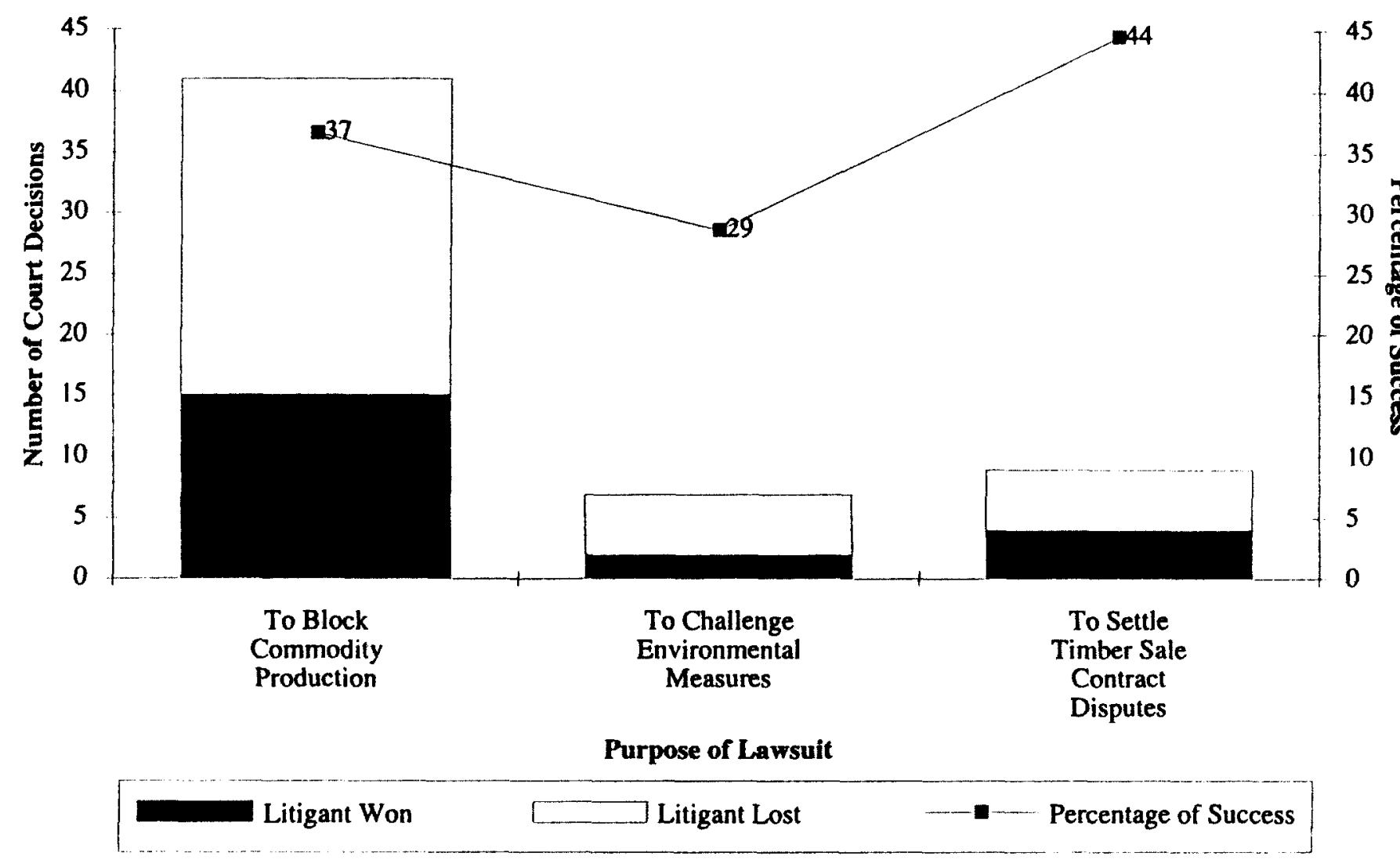

\section{Table 5}

Frequency of Administrative Appeals Brought Against the Forest Service

\section{FY83}

FY84

FY85

FY86

FY87

FY88

FY89

FY90

FY91

FY92

\section{Appeals Brought}

584

439

581

1081

874

1609

1291

1991

1386

1659

\section{Decisions Rendered}

no data

no data

no data

681

809

1193

1290

1787

1182

1486 
Table 6

Forest Service Administrative Appeals by Region, Fiscal Years 1988-1992

\begin{tabular}{lrrrrr}
\hline & FY88 & FY89 & FY90 & FY91 & FY92 \\
Region 1 & 289 & 107 & 132 & 205 & 409 \\
Region 2 & 52 & 44 & 41 & 17 & 67 \\
Region 3 & 89 & 64 & 89 & 85 & 60 \\
Region 4 & 117 & 85 & 196 & 23 & 115 \\
Region 5 & 380 & 247 & 176 & 133 & 160 \\
Region 6 & 440 & 272 & 536 & 396 & 357 \\
Region 8 & 174 & 262 & 651 & 231 & 223 \\
Region 9 & 53 & 174 & 150 & 67 & 111 \\
Region 10 & 15 & 35 & 17 & 15 & 23 \\
Servicewide & 0 & 1 & 3 & 0 & 0 \\
Total Appeals & 1609 & 1291 & 1991 & 1172 & 1525 \\
& & & & &
\end{tabular}

\section{Appeal Outcomes}

Despite the increase in appeals, the data show a fairly low success rate for agency challengers. According to Forest Service numbers, only about $6 \%$ of appeals in 1991 were reversed or remanded to the deciding officer, rulings that indicate the agency was or may have been in error. Of the other $94 \%, 57 \%$ of appealed decisions were affirmed (indicating that they were made correctly), $18 \%$ were dismissed (thrown out by the hearing officer for being untimely, etc.) and $19 \%$ were "closed" (meaning the appeal or decision being appealed was withdrawn by either the plaintiff or the Forest Service). Table 7 shows that these numbers have been relatively constant from 1988 to 1991, except for a steadily increasing number of affirmed cases and a higher number of closed cases in 1990.

\section{Table 7}

Forest Service Administrative Appeals Decisions, Fiscal Years 1988-1992

\begin{tabular}{|c|c|c|c|c|c|c|c|c|c|c|}
\hline & \multicolumn{2}{|c|}{ FY88 } & \multicolumn{2}{|c|}{ FY89 } & \multicolumn{2}{|c|}{ FY90 } & \multicolumn{2}{|c|}{ FY91 } & \multicolumn{2}{|c|}{ FY92 } \\
\hline & \# & $\%$ & \# & $\%$ & \# & $\%$ & \# & $\%$ & \# & $\%$ \\
\hline Affirmed & 455 & 38 & 522 & 41 & 615 & 35 & 679 & 57 & 1040 & 70 \\
\hline Reversed/ & & & & & & & & & & \\
\hline Remanded & 62 & 5 & 89 & 7 & 125 & 7 & 73 & 6 & 111 & 7 \\
\hline Dismissed & 376 & 32 & 323 & 26 & 304 & 17 & 211 & 18 & 159 & 11 \\
\hline Closed & 300 & 25 & 331 & 26 & 726 & 41 & 219 & 19 & 176 & 12 \\
\hline Total & & & & & & & & & & \\
\hline Decisions & 1193 & 100 & 1265 & 100 & 1770 & 100 & 1182 & 100 & 1486 & 100 \\
\hline
\end{tabular}

Moreover, the agency's own numbers indicate that the ultimate impact on resource activity has been relatively small. Only $16 \%$ of the volume of timber sales worth more than $\$ 300$ in value were appealed in 1991, and appeals were credited with preventing the sale of only 5\% (litigation reportedly impacted another 14\%) (United States Department of Agriculture, Forest Service, 1991). Agency personnel also report that only about $1 \%$ of unsuccessful appeals actually make it to litigation in the court system (Coulombe, 1993). This has resulted in a widespread agency belief that the 
primary impact of the appeals process is to delay decisions, not change them (Coulombe, 1993). However, it may be that the primary impact of administrative appeals on the agency is to cause agency officials proactively to adjust their decisions to avoid additional appeals and associated time and resource costs (Culhane, 1981).

\section{Qualitative Analysis of On-the-ground Impact of NFMA Decisions}

Use of both the courts and administrative appeals process has been increasing. Although success is far from guaranteed, particularly with administrative appeals, it appears to occur often enough to make litigation worthwhile as a tool to attempt changes in National Forest management activities. Obtaining a favorable court or administrative decision is one potential indicator of the success different parties have had in using the judicial system or appeals process to influence agency actions. However, receiving an amenable ruling does not necessarily result in any lasting, onthe-ground change in resource management. To address the question of whether the courts have had any significant role in instigating meaningful change in the Forest Service, the impacts were examined of the five NFMA forest planning lawsuits that the agency lost. However, because of space limitations we discuss in the following pages only the three cases related to the spotted owl controversy in the Pacific Northwest. Nevertheless, in our analyses of the other two cases (Citizens for Environmental Quality v. United States and Sierra Club v. Cargill) we found patterns similar to those for the spotted owl cases.

\section{"Spotted Owl Cases"}

In one of the spotted owl cases, Seattle Audubon Society v. Evans, the appellate court upheld District Court Judge Dwyer's decision to grant a permanent injunction against federal timber sales in the owl's habitat throughout the Pacific Northwest until the Forest Service complied with NFMA by adopting standards and guidelines to ensure the owl's viability (952 F.2d 297, 9th Cir. 1991). Dwyer's decision had been unequivocal in its message:

More is involved here than a simple failure by an agency to comply with its governing statute. The most recent violation of NFMA exemplifies a deliberate and systematic refusal by the Forest Service and the FWS to comply with the laws protecting wildlife. This ... reflects decisions made by higher authorities in the executive branch of the government (771 F.Supp. 1081, W.D. Wash. 1991).

Judge Schroeder agreed with Dwyer, maintaining that the bird's designation as threatened by the United States Fish and Wildlife Service did not excuse the Forest Service from its obligation to maintain a viable population of species under NFMA (952 F.2d 297, 9th Cir. 1991).

In a continuation of this issue, the same organization and other environmental groups sued the Forest Service three months later in Seattle Audubon Society v. Moseley, where they claimed that the newly-written EIS violated NFMA, NEPA, and the Administrative Procedures Act by failing to assure the viability of the owl (92-479, W.D. Wash. 1992). Again, Dwyer found that the agency had not satisfied its statutory obligations fully, this time regarding NEPA. Subsequent court orders during the summer of 1992 continued the injunction on timber sales and established a compliance schedule for the agency. The Administration completed its rewritten EIS in July 1993, 
following President Clinton's Forest Summit in April, and released its final management plan and EIS in the spring of 1994.

The same species also was involved in a minor case, Sierra Club v. Butruille, in which environmentalists filed a complaint against the Forest Service for not deciding their administrative appeals relating to land resource management plans for the Wenatchee, Okanogan, and Mt. Baker-Snoqualmie National Forests, which were linked to the spotted owl controversy (92-344, W.D. Wash. 1992). Judge Dwyer ruled that the agency could not proceed with implementation of certain parts of the current forest plans until the Chief had reviewed the appeals. However, most of these activities were already on hold due to the other pending injunctions (92-344, W.D. Wash. 1992).

Both sides are in clear agreement that the "spotted owl cases" are having a significant impact on National Forest management. "In the short term it would be hard to deny that nothing is happening [as a result of the suits]," said one Forest Service staff person, "because nothing is happening in spotted owl habitat" (Reifenberg, 1993). Virtually all timber sales in the old growth of the Pacific Northwest-the owl's habitat-were put on hold. Todd True (1993), the Sierra Club Legal Defense Fund attorney who litigated the two Seattle Audubon Society cases, maintains that the "full report is not yet in," but feels the cases' impacts extend well beyond the mere halt of timber sales:

The case was brought against the Forest Service on the owl because the plan wasn't scientifically sound. So the Forest Service put together a team to create a scientific plan and gave them the freedom to do such a plan. The new plan was a dramatic departure from anything previously on the Forest Service's radar screen. The lawsuit opened the door for the Forest Service scientists to tell the truth.

Although Tom Nygren (1993), Director of Strategic Planning for the Forest Service's Pacific Northwest Region, speculates that the agency may have arrived at the same place a decade later without the lawsuits, he also shares many of True's views on the court decision's effect. True (1993) maintains that the case "forced the science" and "speeded things up," leading to a "new scientific viewpoint which has had a major impact." According to Nygren (1993), "the agency historically has had a predisposition not to act quickly in response to new scientific information because of the huge potential impact." He described it with an analogy: "Say you have ... a cavity. You may not go to the dentist until you get a toothache. The judge was the toothache in this case.... I think it was good. The sooner we deal with it, the better. The more options we'll have." Other environmentalists are even more optimistic: "The Dwyer decision has the potential not only to set a precedent for all threatened and endangered species, but also to signal a warning to federal agencies that they cannot continue to operate outside the law" (Save America's Forests, 1992b, p. 11).

According to True (1993), these court cases played a "catalyst" role in helping to change Forest Service policies:

You can't point to any one thing as the sole source of change. But lawsuits have been the main driving force in the Northwest to change the playing field to make something new happen. If it hadn't been for scientists, environmentalists, sympathetic ears in Congress, it wouldn't have happened either. 
He speculates that the impact may be nationwide, citing the agency's efforts to avoid similar lawsuits by addressing the declining populations of the rare California and Mexican spotted owls before the species were listed.

As indicated earlier, similar patterns and observations were found concening the other two NFMA cases. Altogether, the five NFMA planning lawsuits examined represent but a small sample of Forest Service court cases. Nonetheless, they do provide important insight into the role of the court system in interpreting the Forest Service's responsibilities under its most detailed congressional mandate. Although opinions differ on the magnitude and endurance of the impact, court decisions against the Forest Service appear to play a clear role in catalyzing, and sometimes directly causing, substantive changes in on-the-ground management of forest resources. While it is impossible to project accurately what the outcome might have been without the lawsuits, litigation does appear to change the time frame under which the agency addresses a problem by forcing the issue onto the agency's policy agenda and pushing the agency to view the situation in a new way.

The judicial system also frequently has been a catalyst for the resolution of forest management issues in other policymaking arenas, such as Congress and the White House. Indeed, it was this scenario that led to enactment of NFMA in 1976. Increasing public concern over National Forest management in the mid-1970s resulted in a spate of litigation (Parent, 1992). The controversy climaxed in the West Virginia Division of the Izaak Walton League of America, Inc. v. Butz case in 1975, in which the Fourth Circuit Court enjoined the Forest Service from clearcutting in the Monongahela National Forest, as well as in the rest of the 4th Circuit (522 F.2d 945, 4th Cir. 1975). This ruling virtually eliminated the Forest Service's use of clearcutting in the region, which was the preferred harvest technique of the timber industry (and arguably of the agency itself). The Court maintained that if existing statutes were not providing adequate resolution of conflicts over forest issues, then "the appropriate forum to resolve this complex and controversial issue is not the courts but the Congress" (522 F.2d 955). Congress agreed with the court's assessment of the appropriate separation of powers and reacted immediately to avoid major industry and agency outcry by passing NFMA (Parent, 1992). Claimed Senator Humphrey (1976, p. 33835), in defense of the statute, the goal of NFMA is to "get the practice of forestry out of the courts."

The court system appears to have played a similar role in forcing attention on management of the threatened northern spotted owl. As with the Monongahela decision, the court's strong ruling effectively has pushed the issue into the congressional and White House arena for resolution. Most credit Dwyer's court injunction on Northwest timber sales with inspiring the newly-elected President, Bill Clinton, to hold a Forest Summit in the spring of 1993 and to pledge his commitment to developing a solution to address the spotted owl issue (True, 1993). It is widely believed that if the President's proposed management plan fails to pass judicial scrutiny, or if the implementation of timber sales under the plan is impeded by lawsuits, that the dispute will be forced back to Congress for final resolution (Jones, 1993).

\section{Summary and Conclusions}

Our analysis shows clearly that the use of litigation and administrative appeals to challenge agency actions has increased dramatically over the past two decades. This provides evidence in favor of our hypothesis that if litigation and appeals are important sources of agency influence, then we should see increasing frequency in their use to 
coincide with recent evidence of change within the Forest Service. Although not conclusive proof in and of itself, such a trend indicates that the judicial system and the administrative appeals process likely have been significant factors in effecting change in the agency.

The use of these legal tools is not uniform throughout the country, but is focused mostly in the western United States, particularly the Pacific Northwest, where intensive commodity use of the National Forests has created some of the most controversial resource management issues. The Ninth Circuit Court in this region also is perceived as being more sympathetic to environmental concerns-an observation bolstered by our findings of higher litigant success rates there-making litigation a more attractive change agent to utilize in this circuit.

An examination of the instigators and purposes of lawsuits found that litigation is used most frequently by environmentalists, and most often to block commodity production activities by the agency. Given the Forest Service's traditional focus on timber production (Twight, 1983; Dana \& Fairfax, 1980), environmental interests have had more reason to use litigation to try to force change within the agency. In addition, NEPA, NFMA, and the other environmental laws of that era were enacted to force the federal agencies to place greater emphasis on environmental protection and non-commodity forest uses, and hence are likely to be more useful legal tools for environmental litigants than their commodity counterparts. However, if Forest Service emphasis begins to push the pendulum back in the other direction, it is quite possible that commodity interests' use of the court system to challenge agency decisions will increase.

Our analysis also found that litigants bringing suits to impede commodity production activities by the Forest Service, such as timber sales and roadbuilding, have enjoyed a higher success rate than have litigants seeking to promote commodity production or to challenge additional resource protection activities by the agency. This finding indicates that court-induced agency change via NEPA and NFMA has been more often in the direction of favoring environmental protection and non-commodity forest uses than in emphasizing commodity production activities such as logging and mining. Such results corroborate a recent survey of interest groups involved in USFS forest planning, which found that non-consumptive forest users felt that the courts and judicial review of agency actions had significantly positive influences upon change in the Forest Service since 1976, whereas consumptive users thought the opposite (Jones \& Mohai, 1995). Again, this likely is due to the fact that the courts are interpreting and holding the agency accountable to environmental legislation such as NEPA and NFMA that was enacted by Congress to increase environmental sensitivity in agency decisionmaking and to ensure multiple uses of the National Forests (Wenner, 1982). Given that recently-observed change in the Forest Service has been in the net direction of non-commodity forest uses (Farnham, 1995; Farnham \& Mohai, 1995; Farnham, Taylor, \& Callaway, 1995; Jones \& Mohai, 1995; Mohai, Stillman, Jakes, \& Liggett, 1994; Brown \& Harris, 1992a; McCarthy, Sabatier, \& Loomis, 1991), the higher success rates found for litigants seeking environmental protection goals provides additional evidence for claims that the courts are an important source of change within the Forest Service.

Even though the agency wins the majority of suits in which it is involved, qualitative evidence from the five NFMA lawsuit case studies reveals that when litigants are successful in legal challenges against the agency, the court decision often results in substantive on-the-ground changes in management, thereby providing an incentive for additional use of litigation to alter agency actions. In addition, lawsuits often serve as catalysts for the debate and subsequent resolution of a particular resource 
management issue in another policy arena. These observations further advance the notion that litigation likely has been a significant source of Forest Service change.

Data on administrative appeals are somewhat less conclusive in showing a link with agency change, despite growing use of the appeals process. However, appeals (and lawsuits) do not necessarily have to be won to have an impact; the mere threat of appeals, due to their concomitant delays and increased workload and costs, may influence the Forest Service's decisionmaking before decisions are even made. Culhane (1981) argues via his "rule of anticipated reactions" that the agency, in its desire to avoid conflict, proactively is receptive to the public's response to its activities. According to this theory, if the agency anticipates that an upcoming decision might be challenged, it may alter the decision to ameliorate the objections and avoid the challenge, or at least obtain a more substantial scientific justification for the decision prior to issuing it.

Comments from agency personnel indicate that there likely is some validity to this theory; several claimed that the high resource and opportunity costs of administrative appeals often are foremost in the minds of agency personnel when making decisions. For example, one USFS staff person maintained that the time costs associated with legal challenges impact Forest Service staff by making them "aware of the risk of litigation," causing them to think about "the amount of time it will take to litigate last year's decision while they do this year's work" (Lennahan, 1993). Forest Service documents also allude to a Culhane-type reaction to appeals. For example, an agency critique of its planning process reports, "[W]e are a responsive agency, doing a better job of resource management because of the appeals process" (United States Department of Agriculture, Forest Service, 1990b, p. 16). The agency's annual summary of appeal activity for 1992 also reported that 85 timber sales were "reanalyzed due to appeals" although the sales themselves were not appealed (United States Department of Agriculture, Office of the General Counsel, 1993). Similarly, the spotted owl litigation has caused the Forest Service to begin screening all Northwest timber sales on the east side of the Cascade mountains for their impacts on at-risk species.

Use of litigation and administrative appeals to force agency change incurs significant time and money costs for both the Forest Service and the external interests that initiate the challenges. Such resource expenditures represent significant opportunity costs; if alternative means were found to resolve conflicts, these finite resources could be spent by both sides in more productive ways to enhance the stewardship of our forests. Moreover, lawsuits and appeals often exacerbate the controversy and polarization surrounding resource use dilemmas, and impede positive working relationships between the agency and outside interests. As a result, it is safe to say that legal challenges probably are not the ideal means to develop long-term strategies for the resource management of our National Forests.

Nonetheless, despite the costs, access to both the courts and the administrative appeals process is viewed by the public and by organized interest groups as an important component of public involvement (Inner Voice, 1992). Attempts by either the agency or Congress to limit it therefore have been (and likely will continue to be) viewed as a restriction of citizen rights. As a result, Congress and the Forest Service may be served better by focusing more on trying to defuse conflicts over resource use via increased public participation in the development of forest plans, rather than by restrictions on judicial review or further alterations of the agency's administrative appeals process-in other words, treating the cause rather than the symptom. With true public involvement in the planning process, the public will develop more of a vested ownership in the plan and may feel less need to resort to an adversarial appeals process. 
Yet having the option available will preclude the perception that they have been deprived of their rightful access to review of agency decisions.

Elise S. Jones is the natural resources legislative assistant for United States Representative Elizabeth Furse, who represents the First District of Oregon. Ms. Jones has a B.S. in natural resources from Cornell University and has worked on federal environmental policy issues in Washington, DC for six years. At the time of the research, she was a graduate student at the School of Natural Resources and Environment of the University of Michigan, Ann Arbor, where she went on to receive an M.S. in natural resources policy.

Cameron Proffitt Taylor works currently in the Environment Program of the Office of Technology Assessment, United States Congress. Ms. Taylor conducts indepth policy analysis, at the request of congressional committees, on complex science and technology issues related specifically to the environment. In April 1993, Ms. Taylor completed her M.S. in resource policy and administration at the University of Michigan's School of Natural Resources and Environment. Prior to graduate school, Ms. Taylor worked for the National Wildlife Refuge Association. This article summarizes Ms. Taylor's graduate research project.

\section{References}

Ackerman, S. (1990). Observations on the transformation of the Forest Service: The effects of the National Environmental Policy Act on U.S. Forest Service decision making. Environmental Law, 20 (2), 703-734.

Benfield, K. (1993, March 5). Personal communication with Kaid Benfield, Senior Attorney, Natural Resources Defense Council.

Bolduan, L. M. (1990). The Hatfield riders: Eliminating the role of the courts in environmental decision making. Environmental Law, 20 (1), 329-385.

Brown, G., \& Harris, C. C. (1992a). The U.S. Forest Service: Toward the new resource management paradigm? Society \& Natural Resources, 5, 231-245.

Brown, G., \& Harris, C. C. (1992b). The U.S. Forest Service: Changing of the guard. Natural Resources Journal, 32, 449-466.

Brown, G., \& Harris, C. C. (1993). The implications of workforce diversification in the U.S. Forest Service. Administration and Society, 25 (1), 85-113.

Coulombe, M. (1993, March 5). Personal communication with Mary Coulombe, Policy Analyst, United States Department of Agriculture.

Culhane, P. J. (1981). Public lands politics: Interest group influence on the Forest Service and the Bureau of Land Management. Baltimore, MD: Johns Hopkins University Press.

Cutler, M. R. (1972). A study of litigation related to management of Forest Service administered lands and its effects on policy decisions. Unpublished doctoral dissertation, Michigan State University, East Lansing, Michigan.

Dana, S. T., \& Fairfax, S.K. (1980). Forest and range policy. New York, NY: McGraw-Hill Book Company.

Farnham, T. (1995). Forest Service budget requests and appropriations: What do analyses of trends reveal? Policy Studies Journal, 23 (2), 253-267.

Famham, T., \& Mohai, P. (1995). National forest timber management over the past decade: A change in emphasis for the Forest Service? Policy Studies Journal, 23 (2), 268-280.

Famham, T., Taylor, C. P., \& Callaway, W. (1995). A shift in values: Non-commodity resource management and the Forest Service. Policy Studies Journal, 23 (2), 281-295.

Hauser, K. (1990, October 25). Year-end report on servicewide appeals activity. Memo from Kathryn Hauser, Washington Office Appeals Coordinator, United States Department of Agriculture, Forest Service to Deputy Chief, United States Department of Agriculture, Forest Service.

Hill, L. W. (1988, October 11). Recap of FY 88 appeal activity in WO. Memo from Lawrence W. Hill, Staff Assistant for Operations, National Forest System, United States Department of Agriculture, Forest Service, to Deputy Chief, United States Department of Agriculture, Forest Service. 
Honnold, D. (1993, March 4). Personal communication with Doug Honnold, Attorney, Sierra Club Legal Defense Fund, Colorado Office.

Humphrey, H. H. (1976). 122 Congressional Record, p. 33835.

Inner Voice. (1992, May/June). An Unappealing Proposal. Inner Voice, p. 3.

Jablonski, R. (1993, March 4). Personal communication with Ron Jablonski, Public Affairs Officer, Rio Grande National Forest, United States Department of Agriculture, Forest Service.

Jones, E. S., \& Callaway, W. (1995). Neutral bystander, intrusive micromanager, or useful catalyst? The role of Congress in effecting change within the Forest Service. Policy Studies Journal, (23) 2, 337-350.

Jones, E. S., \& Mohai, P. (1995). Is the Forest Service keeping up with the times? Interest group and forestry school perceptions of post-NFMA change in the United States Forest Service. Policy Studies Journal, (23) 2, 351-371.

Jones, S. (1993, November 21). Personal communication with Suzanne Jones, Endangered Species Act Legislative Representative, National Wildlife Federation.

Kennedy, J. J. (1991). Integrating gender diverse and interdisciplinary professional into traditional U.S. Department of Agriculture-Forest Service culture. Society and Natural Resources, 4, 165.

Kennedy, J. J. (1988). Legislative confrontation of groupthink in U.S. natural resource agencies. Environmental Conservation, 15 (2), 123-128.

Lennahan, C. (1993, March 5). Personal communication with Charles Lennahan, Attorney, United States Department of Agriculture, Office of General Counsel, Denver Office.

McCarthy, C., Sabatier, P., \& Loomis, J. (1991). Attitudinal change in the Forest Service: 1960-1990. Paper presented at the 1991 Annual Meeting of the Westem Political Science Association, Seattle, WA.

Mohai, P. (1987). Public participation and natural resource decision-making: The case of the RARE II decisions. Natural Resources Journal, 27 (1), 123-155.

Mohai, P., Stillman, P., Jakes, P., \& Liggett, C. (1994). Change in the USDA Forest Service: Are we heading in the right direction? General Technical Report NC-172. St. Paul, MN: United States Department of Agriculture, Forest Service, North Central Forest Experiment Station.

Mohai, P., \& Jakes, P. (in press). The Forest Service in the 1990s: Is it heading in the right direction?-A view from agency employees. Journal of Forestry.

Mulach, R. (1993). List of Published Forest Service NFMA Cases. Washington, DC: United States Department of Agriculture, Forest Service.

Nygren, T. (1993, March 5). Personal communication with Tom Nygren, Director, Strategic Planning, Pacific Northwest Region, United States Department of Agriculture, Forest Service.

Parent, S. M. (1992). The National Forest Management Act: Out of the woods and back to the courts? Environmental Law, 22 (2), 699-702.

Plater, Z. J. B., Abrams, R. H., \& Goldfarb, W. (1992). Environmental law and policy: A coursebook on nature, law and society. St. Paul, MN: West Publishing Co.

Reifenberg, A. (1993, March 5). Personal communication with Arno Reifenberg, Attorney, Office of General Counsel, United States Department of Agriculture, Pacific Northwest Region.

Robichaud, S. A. (1991). Lujan v. National Wildlife Federation: The Supreme Court tightens the reins on standing for environmental groups. Catholic University Law Review, 40 (2), 443-474.

Save America's Forests. (1992a, Spring). Administration attacking citizen rights: Forest Service to eliminate appeals process. Coalition Report, pp. 1-7.

Save America's Forests. (1992b). The Endangered Species Act: An endangered law. Save America's Forests: D.C. update, $3(1), 11,13$.

Smith, R. (1993, March 5). Personal communication with Rocky Smith, Forest Specialist, Colorado Environmental Coalition.

Thomas, J. C., \& Mohai, P. (1995). Racial, gender, and professional diversification in the Forest Service from 1983 to 1992. Policy Studies Journal, 23 (2), 296-309.

Tipple, T. J., \& Wellmann, J. D. (1991). Herbert Kaufman's forest ranger thirty years later: From simplicity and homogeneity to complexity and diversity. Public Administration Review, 51 (5), 421-428.

True, T. (1993, March 5). Personal communication with Todd True, Staff Attorney, Sierra Club Legal Defense Fund.

Twight, B. W. (1983). Organizational value and political power: The Forest Service versus the Olympic National Park. University Park and London: Pennsylvania State University Press.

United States Department of Agriculture, Forest Service. (1990a). Servicewide appeal activity FY 1989. Washington, DC: Author.

United States Department of Agriculture, Forest Service. (1990b). Usefulness of forest plans. Critique of land management planning (vol. 8). Washington, DC: Author.

United States Department of Agriculture, Forest Service. (1991). Servicewide appeal activity FY 1991. Washington, DC: Author. 
Policy Studies Journal, 23: 2

United States Department of Agriculture, Forest Service. (1992a). Consent decree: Forest Service briefing paper for the FY 1993 budget request. Washington, DC: Author.

United States Department of Agriculture, Forest Service. (1992b). FY 1992 year-end report on servicewide appeal activity. Washington, DC: Author.

United States Department of Agriculture, Office of the General Counsel. (1993, January). LMRPINFMA forest planning litigation scorecard. Washington, DC: Author.

Vail, J. T. (1993). Litigation statistics on Forest Service NEPA cases. Washington, DC: United States Department of Agriculture, Office of the General Counsel.

Wenner, L. M. (1982). The environmental decade in court. Bloomington: Indiana University Press. 
This document is a scanned copy of a printed document. No warranty is given about the accuracy of the copy. Users should refer to the original published version of the material. 